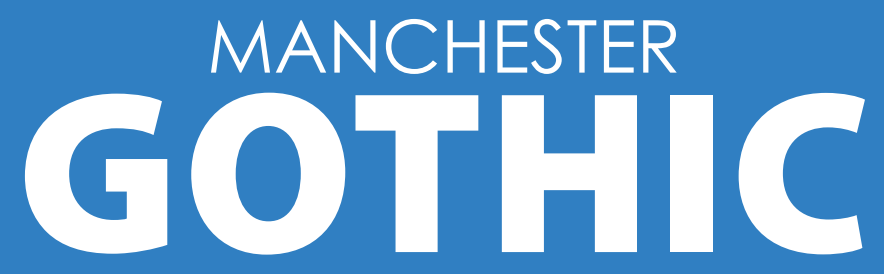

\title{
GUROPEAN GOTHIO
}

A spirited exchange 1760-1960

EDITED BY AVRIL HORNER

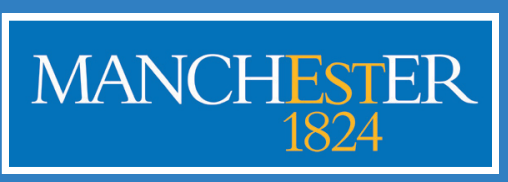

Manchester University Press

www.manchesteruniversitypress.co.uk 


\section{European Gothic}


Avril Horner - 9781526125699 Downloaded from manchesterhive.com at 04/26/2023 08:04:47AM via free access 


\section{European Gothic}

A spirited exchange 1760-1960

edited by

AVRIL HORNER

MANCHESTER UNIVERSITY PRESS

Manchester 
Copyright ( Manchester University Press 2002

While copyright in the volume as a whole is vested in Manchester University Press, copyright in individual chapters belongs to their respective authors, and no chapter may be reproduced wholly or in part without the express permission in writing of both author and publisher.

Published by Manchester University Press

Altrincham Street, Manchester M1 7JA, UK

www.manchesteruniversitypress.co.uk

British Library Cataloguing-in-Publication Data

A catalogue record for this book is available from the British Library.

Library of Congress Cataloging-in-Publication Data applied for

ISBN $071906063 \mathrm{X}$ hardback

0719060648 paperback

ISBN 9781526125699 Institutional

First published 2002

100908070605040302

10987654321

Typeset by

Northern Phototypesetting Co. Ltd., Bolton 